\title{
Review of Municipal Sludge Use as a Soil Amendment on Disturbed Lands
}

\author{
C. A. Brandt \\ P. L. Hendrickson
}

August 1990

Prepared for the U.S. Department of Energy under Contract DE-AC06-76RLO 1830

Pacific Northwest Laboratory Operated for the U.S. Department of Energy by Battelle Memorial Institute 


\title{
DISCLAIMER
}

This report was prepared as an account of work sponsored by an agency of the United States Government. Neither the United States Government nor any agency thereof, nor Battelle Memorial Institute, nor any of their employees, makes any warranty, expressed or implied, or assumes any legal liability or responsibility for the accuracy, completeness, or usefulness of any information, apparatus, product, or process disclosed, or represents that its use would not infringe privately owned rights. Reference herein to any specific commercial product, process, or senvice by trade name, trademark, manufacturer, or otherwise, does not necessarily constitute or imply its endorsement, recommendation, or favoring by the United States Government or any agency thereof, or Battelle Memorial Institute. The views and opinions of authors expressed herein do not necessarily state or reflect those of the United States Government or any agency thereof.

\author{
PACIFIC NORTHWEST LABORATORY \\ operated by \\ BATTELLE MEMORIAL INSTITUTE \\ for the \\ UNITED STATES DEPARTMENT OF ENERGY \\ under Contract DE-AC06-76RLO 1830
}

Printed in the United States of America

Available to DOE and DOE contractors from the

Office of Scientific and Techuical Information, P.O. Box 62, Oak Ridge, TN 37831; prices available from (615) 576-8401. FTS 626-8401.

Available to the public from the National Technical Information Service, U.S. Department of Commerce, 5285 Port Royal Rd., Springficld, VA 22161.

NTIS Price Codes, Microfiche A01

Printed Copy

\begin{tabular}{ccccc}
\hline Price Code & Page Range & & Price Code & Page Range \\
\cline { 5 - 5 } A02 & $1-10$ & & A15 & $326-350$ \\
A03 & $11-50$ & & A16 & $351-375$ \\
A04 & $51-75$ & & A17 & $376-400$ \\
A05 & $76-100$ & & A18 & $401-425$ \\
A06 & $101-125$ & & A19 & $426-450$ \\
A07 & $126-150$ & & A20 & $451-475$ \\
A08 & $151-175$ & & A21 & $476-500$ \\
A09 & $176-200$ & & A22 & $501-525$ \\
A10 & $201-225$ & & A23 & $526-550$ \\
A11 & $226-250$ & & A24 & $551-575$ \\
A12 & $251-275$ & A25 & $576-600$ \\
A13 & $276-300$ & A99 & $601-U$ P \\
A14 & $301-325$ & &
\end{tabular}




\title{
REVIEW OF MUNICIPAL SLUDGE USE AS A SOIL AMENDMENT ON DISTURBED LANDS
}

\author{
C. A. Brandt \\ P. L. Hendrickson
}

August 1990

Prepared for the U.S. Department of Energy under Contract DE-AC06-76RLO 1830

Pacific Northwest Laboratory

Richland, Washington 99352 



\section{SUMMARY}

The U.S. Department of Energy is examining options for improving soil conditions at Hanford reclamation sites. One promising technology is the incorporation of municipal sewage sludge into the soil profile. This report reviews the potential benefits and adverse consequences of sludge use in land reclamation.

Land reclamation comprises those activities instigated to return a mechanically disturbed site to some later successional state. Besides the introduction of suitable plant species to disturbed lands, reclamation generally requires measures to enhance long-term soil nutrient content, moisture retention or drainage, and mitigation of toxic effects from metals and $\mathrm{pH}$. One of the more effective means of remediating adverse soil characteristics is the application of complex organic manures such as municipal sewage sludge. Sewage sludges contain complete macro- and micronutrients necessary to sustain plant growth. The application of sewage sludge may reestablish microbial activity in sterile soils. Physical properties, such as water-holding capacity and percentage water-stable aggregates, also improve with the addition of sewage sludge. Sludge applications may also increase the rate of degradation of some hydrocarbon pollutants in soils.

Potential adverse impacts associated with the application of sewage sludge to land include negative public perception of human waste products; concerns regarding pathogen buildup and spread in the soils, plants, and water; entrance and accumulation of heavy metals in the food chain; salt accumulation in the soil and ground water; leaching of nitrates into ground water; and accumulation of other potentially toxic substances, such as boron and synthetic hydrocarbons, in the soil, plants, and food chain.

Many municipal sewage sludges contain appreciable amounts of heavy metals and other potentially toxic trace elements. The sources of these metals are largely industrial effluents treated in the municipal sewage treatment plants. Most trace elements are relatively immobile in soils, being strongly complexed with soil organic matter or adsorbed to soil minerals. Consequently, even when grown in heavily contaminated soils, few crops absorb sufficient amounts of copper, nickel, or zinc to affect the health of ruminants. Cobalt may be concentrated by plants in sufficient quantities to constitute a health risk to consumers; however, cobalt levels in most sewage sludges are sufficiently low that concentrations in plants grown on sludge-amended soils would not reach harmful levels. Cadmium and polychlorinated biphenyls are regulated by the U.S. Environmental Protection Agency (EPA) when the sludge is applied to land used for the production of animal feed or food-chain crops. Various states and the U.S. Department of Agriculture's regional technical committees recommend controlling sludge application rates on the basis of trace elements other than cadmium. Leaching of nitrates into ground 
water is considered a potential negative factor in the use of all nitrogenous fertilizers. However, sludges are less prone to leaching than are commercial fertilizers.

Regulatory requirements applicable to use of municipal sewage sludge as a soil supplement on disturbed lands exist at the federal, state, and local level. The basis for the requirements is Section 405 of the federal Clean Water Act. Regulatory requirements are currently in a period of transition as EPA implements the directives in Section 405.

Measures to mitigate potential adverse effects of sewage sludge used as a soil amendment include defining design criteria for land application programs; assessing risks to wildlife and human health associated with pathogens, halogenated hydrocarbons, and heavy metals; permitting for sludge use by state and/or local health departments; land use restrictions; application rate restrictions; monitoring requirements; sludge analysis requirements regarding metals, nitrogen, and halogenated hydrocarbons; and refinement and codification of operational procedures covering production, transport, application systems, year-round operation, storage, and other aspects of sludge management. 


\section{CONTENTS}

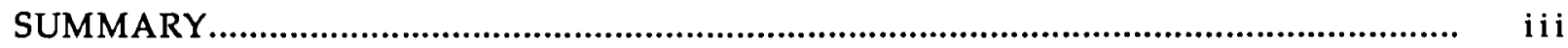

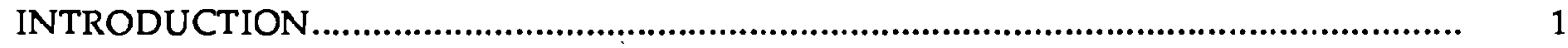

BENEFITS OF SEWAGE SLUDGE FOR LAND RECLAMATION...................................... 3

POTENTIAL ADVERSE IMPACTS OF LAND APPLICATION OF SEWAGE SLUDGE........... 7

NEGATIVE PUBLIC PERCEPTION ................................................................ $\quad 7$

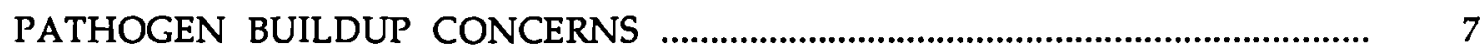

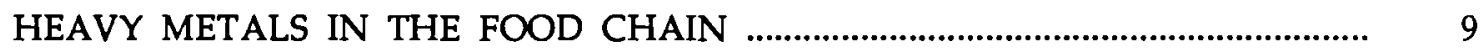

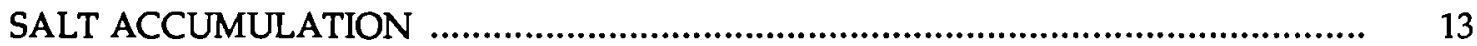

REGULATORY REQUIREMENTS AFFECTING LAND APPLICATION OF SLUDGE............... 15

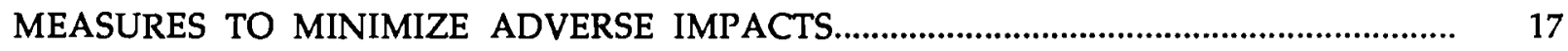

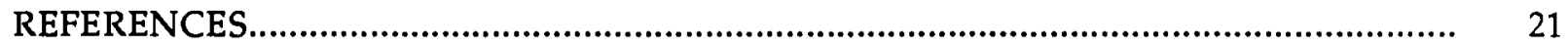





\section{TABLES}

1 Waste Products Used in Land Reclamation and Their Typical Nutrient Contents

2 Organisms of Major Concern in Land Application of Municipal Sludge.............................. 8

3 Half-Life for Selected Microorganisms in Soil Systems ............................................... 8

4 Concentrations of Some Constituents of Digested Sludges...........................................

5 Toxic Concentrations of Elements Found in Municipal Sludge......................................... 10

6 Maximum Annual and Cumulative Cadmium Inputs to

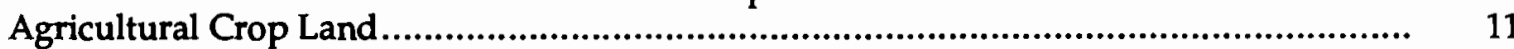

7 Total Soil Loading of Sludge Metals Permitted by the State of Washington..................... 11

8 EPA Guidelines for Total Trace Metal Loadings for Agricultural Lands........................ 12

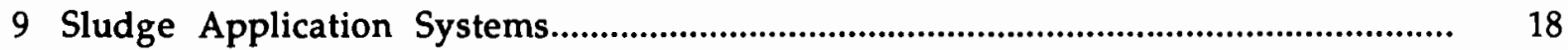

10 Effectiveness of Various Sludge Treatment Processes

in the Reduction of Pathogens.............................................................................................. 19 



\section{INTRODUCTION}

The recent history of Eurasian humankind has been one of increasing change wrought on the landscape as a direct consequence of agricultural, pastoral, mineral, and industrial development. Change in landscapes has progressed from what is often considered to be biotic climax communities with slow turnover in nutrients and energy to early successional communities in which energy and nutrient fluxes may be quite large (Odum 1969). Agricultural practices intentionally keep communities in an early successional state; incidental disturbances such as those associated with mining, roadbuilding, and construction generally produce lands in various states of degradation that are unable to support stable communities of perennial plants. Secondary succession on these lands may take from a few to many hundreds of years, depending primarily on moisture and temperature regimes.

Land reclamation comprises those activities instigated to return a disturbed site to some later successional, usually climax, state. Besides the introduction of suitable plant species to disturbed lands, reclamation generally requires measures to enhance long-term soil nutrient content, moisture retention or drainage, and mitigation of toxic effects caused by metals and $\mathrm{pH}$. One of the more effective means of remediating adverse soil characteristics is the application of complex organic manures and composts.

Disposal of municipal sewage sludge is becoming an increasingly important problem as human populations continue to expand in size. Humans produce an average of $1 \mathrm{ft}^{3}$ of dried sanitary waste per person per year (Jones 1981). Current means of disposal of such waste in the United States include incineration, land filling, ocean dumping, miscellaneous manufacturing, and as a soil amendment or fertilizer. The U.S. Department of Energy is currently examining the feasibility of using municipal sewage sludge as a soil amendment on Hanford Site reclamation areas. This report reviews the known benefits and potential adverse consequences of the use of sewage sludge as an amendment to disturbed soils as part of a land reclamation program. Regulatory requirements affecting land application of sewage sludge are reviewed, and methods to minimize adverse impacts are presented.

Manures of all kinds have been used as fertilizer since prehistory (EPA 1979). With a median content of $40 \%$ organic matter, $3.7 \%$ nitrogen, $1.7 \%$ phosphorus, and $0.3 \%$ potassium (dry weight basis), sewage sludges contain a large amount of plant nutrients in proportions compatible with the requirements of most plants.

Human manure has been applied to lands in Europe and Asia in historical times primarily as a means of supplying nutrients for crop production (Jones 1981). For example, treated sewage from Paris, France, has been used since 1897 to fertilize and irrigate vegetables grown for sale in that city. In the United States, one of the most successful sewage sludge fertilizers with a wide-spread market is 
Milorganite, ${ }^{(0)}$ an activated sewage sludge product manufactured in Milwaukee, Wisconsin, since the early 1970's. Many municipalities in the United States, including Washington, D.C., are producing similar sewage sludge products. An estimated $25 \%$ of human manure in the United States is returned to the soil, mostly in the production of grass turf (Jones 1981).

Milorganite is a registered trademark of Milwaukee Metropolitan Sewerage District, Milwaukee, Wisconsin. 


\section{BENEFITS OF SEWAGE SLUDGE FOR LAND RECLAMATION}

Sewage sludges contain complete macro- and micronutrients necessary to sustain plant growth. When applied to lands depleted of nutrients, such as mine spoils or degraded agricultural lands, sewage sludges may greatly enhance plant productivity. Lands drastically disturbed by mining operations or other significant alterations of surface contours present significant problems in restoring vegetation cover. These operations eliminate existing vegetation, remove topsoil, and destroy the natural soil profile. Spoils generally have little or no organic matter, plant-available nitrogen, or other major nutrients and are in poor physical condition for supporting plant growth (Box 1978). Fertility and physical condition of such material can be greatly enhanced through the application of sewage sludge. Sludges have been used successfully at a number of mine sites in the United States without harmful side effects such as nitrate contamination of ground or surface waters, pathogen migration, or buildup of toxic substances (e.g., Aldon 1982; Brown and Jackson 1984; Howard et al. 1977; Morin 1981; Sabey et al. 1986; Schneider et al. 1981; Sopper and Kerr 1981; Sopper and Seaker 1983; Sopper et al. 1981).

The application of topsoil to spoils areas or other disturbed sites is one restoration alternative used extensively in reclaiming stripmines. Topsoil may be salvaged and stored at the time of disturbance; otherwise, it must be scalped from undisturbed sites. Scalping is more difficult in areas where topsoils are naturally shallow or are covered by extensive vegetation. An effective alternative to topsoil application is to combine spoils or disturbed soils with organic wastes, including human sewage sludge (Table 1). One of the principal advantages of sewage sludge over other types of soil amendments is that sludge combines the advantages of a balanced fertilizer, organic mulch, soil stabilizer, and soil inoculant in a single medium. Furthermore, sludge contains plant micronutrients, such as calcium, copper, magnesium, and zinc.

Sludges contain both inorganic and organic forms of nitrogen. The major inorganic nitrogen form in sludge is ammonium $\left(\mathrm{NH}_{4}\right)$, which is rapidly converted by soil microorganisms to nitrate $\left(\mathrm{NO}_{3}\right)$. Nitrate is the primary form of nitrogen readily taken up by plants. The organic nitrogen fraction, a form unavailable to plant use, is gradually mineralized to $\mathrm{NH}_{4}$, which is subsequently oxidized to $\mathrm{NO}_{3}$ by nitrifying bacteria in the soil. Most of the nitrogen in sludge is in the organic form. Thus, a primary advantage of sludge is that it contains nitrogen in both quick- and slow-release forms, providing a continuous supply of nitrate-form nitrogen throughout the growing period of the plants.

Similar release rates are not possible with inorganic fertilizers. Sabey et al. (1986) discovered that sludge-amended colliery spoils in Colorado produced greater yields of seeded grasses than did 
TABLE 1. Waste Products Used in Land Reclamation and Their Typical Nutrient Contents ${ }^{(a)}$

Composition, \%

\begin{tabular}{|c|c|c|c|c|c|}
\hline Material & Nitrogen & Phosphorus & Potassium & $\begin{array}{l}\text { Organic } \\
\text { Carbon }\end{array}$ & Problems \\
\hline Farmyard manure & 0.6 & 0.1 & 0.5 & 24 & $\begin{array}{l}\text { Can be toxic if directly } \\
\text { applied to plants }\end{array}$ \\
\hline Pig slurry & 0.2 & 0.1 & 0.2 & 3 & High water content \\
\hline $\begin{array}{l}\text { Poultry manure (broiler) } \\
\text { (battery) }\end{array}$ & $\begin{array}{l}2.3 \\
1.5\end{array}$ & $\begin{array}{l}0.9 \\
0.5\end{array}$ & $\begin{array}{l}1.6 \\
0.6\end{array}$ & $\begin{array}{l}68 \\
34\end{array}$ & $\begin{array}{l}\text { High ammonia levels } \\
\text { High ammonia levels }\end{array}$ \\
\hline $\begin{array}{l}\text { Human sewage sludge } \\
\text { (digested) }\end{array}$ & 3.7 & 1.7 & 0.3 & 45 & Possible toxic metals \\
\hline Peat (partly dried) & 0.1 & 0.005 & 0.002 & 50 & Calcium content \\
\hline Mushroom compost (dried) & 2.8 & 0.2 & 0.8 & 95 & None \\
\hline Domestic refuse & 0.5 & 0.2 & 0.3 & 65 & Miscellaneous objects \\
\hline Straw & 0.5 & 0.1 & 0.8 & 95 & Adverse $\mathrm{C} / \mathrm{N}$ ratio \\
\hline
\end{tabular}

(a) From Bradshaw and Chadwick (1980) and Bastian (1986).

spoils amended only with inorganic nitrogen and phosphorus fertilizers applied at rates equivalent to the nitrogen and phosphorus contained in the sludge. In general, grasses are much more responsive to the amount of nitrogen in soils than are shrubs and forbs (Biondini et al. 1985; Doerr and Redente 1983).

A number of factors influence the rate of nitrogen mineralization from sludges, including soil $\mathrm{pH}$ and moisture content. Increasing soil temperatures causes increased mineralization rates of nitrogen (Terry et al. 1981). Anaerobically digested sludges exhibit slower mineralization than do aerobically digested sludges (Parker and Sommers 1983), and increasing sludge application rates results in slower mineralization rates (Epstein et al. 1978; Parker and Sommers 1983; Sabey et al. 1977). Another variable affecting mineralization is soil type. Sabey et al. (1986) showed that the percentage of organic nitrogen mineralized from sludges over 16 weeks in a laboratory setting ranged from $30 \%$ when applied to stockpiled topsoil to $10 \%$ for sand amendments.

The application of sewage sludge may reestablish microbial activity in sterile soils. Significant increases in the number and variety of microbes and fungi have been noted in soils amended with sewage sludge versus commercial fertilizers (Aldon 1982; Fresquez and Lindemann 1982). Microbial activity improves adverse soil properties and promotes the establishment of plant cover by enhancing nitrification processes (Reeder and Berg 1977) and reestablishing symbiotic fungal associations with plant roots (Barnhisel 1988). 
Sewage sludge is commonly used to improve the physical properties of disturbed or depleted soils (e.g., Bradshaw and Chadwick 1980; Sabey et al. 1986; Sopper and Kerr 1981). Physical properties, such as water-holding capacity and percentage water-stable aggregates, improve in proportion to the amount of sludge added (Hinesley et al. 1982). Schneider et al. (1981) found that soil acidity, water supply capacity, cation-exchange capacity, electrical conductivity, organic carbon content, and carbon/nitrogen ratio were all significantly improved by the use of sludge versus chemical fertilizers on mixed shale and sandstone spoils in Kentucky.

Sludge applications may also increase the rate of degradation of some hydrocarbon pollutants in soils. Using greenhouse experiments, Overcash and Weber (1986) studied loss rates in sludge-amended and control soils of two synthetic hydrocarbons (paradichlorobenzene and di-n-butyl phthalate) listed by the U.S. Environmental Protection Agency (EPA) as priority pollutants. They found no effect of sludge application rate on paradichlorobenzene loss from the soil column, but did find a slight acceleration of di-n-butyl phthalate loss with increasing sludge application levels. 
. 


\section{POTENTIAL ADVERSE IMPACTS OF LAND APPLICATION OF SEWAGE SLUDGE}

Potential adverse impacts associated with the application of sewage sludge to land include negative public perception of human waste products; concerns regarding pathogen buildup and spread in soils, plants, and water; entrance and accumulation of heavy metals in the food chain; salt accumulation in the soil and ground water; leaching of nitrates into ground water; and accumulation of other potentially toxic substances, such as boron and synthetic hydrocarbons, in the soil, plants, and food chain.

\section{NEGATIVE PUBLIC PERCEPTION}

Public acceptance is essential to any land application of municipal sewage sludge. Odors from poorly managed application systems may be the principal issue facing most land application programs (Bastian 1986). This and other concerns have resulted in the promulgation of regulations, land-use ordinances or zoning restrictions, and extensive monitoring requirements that limit the perceived and actual impact to the public (e.g., Ecology 1982a, 1982b; Rogers 1986).

\section{PATHOGEN BUILDUP CONCERNS}

Microorganisms with public health consequences occur in waste streams as a result of the existence of infectious disease in the community (Table 2 ). As much as $10 \%$ of a normally healthy population may be shedding infectious agents at any time (Sobsey and Olson 1983). Other pathogens may be introduced via domestic animals. Wastewater treatment facilities control the spread and proliferation of human pathogens through waters, but treatment facilities do not render sewage aseptic. Contamination of plants and waters by fecal flora is a concern relative to the use of sludge on food plants or in areas near watersheds. The EPA requires monitoring of surface waters near areas where sludges are applied and sets surface-water standards for fecal coliform bacterial counts (EPA 1984).

Once sludge is applied to land, the survival of pathogens is dependent on a number of factors, including soil $\mathrm{pH}$, moisture and organic content, sunlight, and antagonistic soil microflora (Table 3). Transport of bacteria and viruses from sludges applied to lands depends in large part on their adsorption to soil particles. Such movement decreases with increasing ion-exchange capacity, clay content, and organic carbon content. Sludge, because of its high organic content, tightly binds viruses and bacteria, resulting in little if any transport of these organisms away from the locus of application (e.g., Damgaard-Larsen et al. 1977; Gerba 1983). Sopper and Kerr (1981) found no fecal coliforms in samples of soil percolate water for various sewage sludge treatments, including treatments as high as 184 metric tons/ha. 
TABLE 2. Organisms of Major Concern in Land Application of Municipal Sludge (a)

\begin{tabular}{lll} 
Group & \multicolumn{1}{c}{ Organism Name } & \multicolumn{1}{c}{ Primary Disease } \\
Bacteria & $\begin{array}{l}\text { Legionella pneumophila } \\
\text { Salmonella sp. }\end{array}$ & $\begin{array}{l}\text { Acute respiratory disease } \\
\text { Gastroenteritis, typhoid } \\
\text { and paratyphoid fever }\end{array}$ \\
& $\begin{array}{l}\text { Shigella sp. } \\
\text { Vibrio cholerae }\end{array}$ & Bacillary dysentery \\
Helminths & Ascaris sp. & Cholera \\
Protozoa & Giardia lamblia & Ascariasis \\
Viruses & Hepatitis A virus & Giardiasis \\
& Non-a, Non-B hepatitis & Infectious hepatitis \\
& Norwalk-like agents & Hepatitis
\end{tabular}

(a) From Sorber and Moore (1986).

TABLE 3. Half-Life for Selected Microorganisms in Soil Systems $(a)$

\begin{tabular}{lccc} 
& \multicolumn{3}{c}{ Half-Life, $h$} \\
\cline { 2 - 4 } Microorganisms & 1.8 & Mverage & Maximum \\
\cline { 2 - 4 } Fecal coliforms & 24 & 20.9 & 237.6 \\
Salmonella sp. & 22.5 & 37.1 & 184.8 \\
Shigella sp. & 4.5 & 24.5 & 26.8 \\
Viruses & & 11.5 & 415.9
\end{tabular}

(a) From Sorber and Moore (1986).

Mechanical straining through soil interstices prevents percolation of large parasites or their eggs (Sorber and Moore 1986). Natural drying of sludge once applied to land inactivates most parasites that may be present (Gerba 1983). Exposure to viral and bacterial aerosols at land treatment sites where spray irrigation is used is unlikely, especially at distances of $100 \mathrm{~m}$ or more (Gerba 1983). 


\section{HEAVY METALS IN THE FOOD CHAIN}

Many municipal sewage sludges contain appreciable amounts of heavy metals and other potentially toxic trace elements (Table 4). The sources of these metals are largely industrial effluents treated in the municipal sewage treatment plants. Other sources include domestic water supplies, chemicals added during water treatment, metals in water storage facilities and piping (e.g., copper or zinc from galvanized piping), and the wastewater treatment process itself. Consequently, sludges from different treatment plants differ greatly in the specific amounts and types of metals and other toxic elements present (as shown in Table 4).

Copper and zinc are trace elements essential to plant growth. However, they may be toxic to plants if supplied in excessive amounts. Lead, nickel, and cadmium are relatively nontoxic to plants, but are much more toxic to animals (Table 5). Heavy metals may be taken up by plants growing in a contaminated medium and become concentrated in foliage and roots (Morin 1981); however, most trace elements, with the exception of boron and chromium, are nearly immobile in most soils (Bradshaw and Chadwick 1980). The amounts taken up by vegetation are generally small compared with the amounts present in the soil (Page et al. 1981). Consequently, plants and wildlife in forests that have been irrigated with liquid sewage sludges generally exhibit little evidence of accumulations of trace metals

TABLE 4. Concentrations of Some Constituents of Digested Sludges (a)

\begin{tabular}{l} 
Property \\
\hline Metals, ppm dry weight \\
Arsenic \\
Cadmium \\
Chromium \\
Copper \\
Lead \\
Mercury \\
Nickel \\
Selenium \\
Zinc \\
Persistent Organic Constituents, Ppm dry weight \\
Polychlorinated biphenyls \\
Chlordane \\
Dieldrin \\
Pathogens \\
Virus, purified filterable units $/ 100 \mathrm{~mL}$ \\
Coliform bacteria, $10^{6} / 100 \mathrm{~mL}$ \\
Salmonella sp., per $100 \mathrm{~mL}$ \\
Pseudomonas sp., per $100 \mathrm{~mL}$
\end{tabular}

\begin{tabular}{rlc} 
Range & Median \\
\cline { 2 - 3 } 3 to 0 & 14 \\
5 & to 2,000 & 15 \\
50 & to 30,000 & 1,000 \\
250 to 17,000 & 1,000 \\
1366 to 7,600 & 1,500 \\
3.4 to 18 & 6.9 \\
25 & to 8,000 & 200 \\
1.7 & to 8.7 & - \\
500 & to 2,000 & 2,000 \\
1.2 & to 105 & 3.2 \\
3 & to 30 & - \\
0.3 & to 2.2 & 0.16 \\
& & 0.85 \\
& & 0.4
\end{tabular}

(a) From NAS (1977). 
TABLE 5. Toxic Concentrations of Elements Found in Municipal Sludge ${ }^{(a)}$

\begin{tabular}{|c|c|c|c|}
\hline Element & $\begin{array}{c}\text { Plants, } \\
\mathrm{mg} / \mathrm{L} \text { in nutrient solution }\end{array}$ & $\begin{array}{r}\text { Rats, } \\
\mathrm{mg} / \mathrm{d} \\
\end{array}$ & $\begin{array}{c}\text { Humans, } \\
\mathrm{mg} / \mathrm{d}\end{array}$ \\
\hline Arsenic & 0.02 to 7.5 & 0.6 & 5 to 0 \\
\hline Boron & 1 to 5 & 0.15 & 4000 \\
\hline Cadmium & 0.2 to 9 & 0.5 & 3 to 30 \\
\hline Chromium & 0.5 to 10 & 5 & 200 \\
\hline Copper & 0.5 to 8 & 1 to 5 & - \\
\hline Lead & 3 to 20 & - & 1 \\
\hline Mercury & 6.6 & $>0.05$ & 0.4 \\
\hline Nickel & 0.5 to 2 & 50 & - \\
\hline Selenium & 1 to 2 & 0.004 to 0.06 & 5 \\
\hline Zinc & 60 to 400 & 50 & 150 to 600 \\
\hline
\end{tabular}

(a) From Bowen (1979) and Bradshaw and Chadwick (1980).

from the sludges (Urie 1986; Woodward et al. 1986). With repeated applications, however, toxic elements will tend to accumulate in the soils, even though they may not constitute a hazard to the ground water.

Even when grown in heavily contaminated soils, few crops absorb sufficient amounts of copper, nickel, or zinc to affect the health of ruminants (Logan and Chaney 1983). Cobalt may be concentrated by plants in sufficient quantities to constitute a health risk to consumers (Logan and Chaney 1983). However, cobalt levels in most sludges are sufficiently low that concentrations in plants grown on sludge-amended soils would not reach harmful levels (Chaney 1980). Molybdenum and selenium may also accumulate in crop plants to levels toxic to ruminants (Allaway 1968). However, molybdenum accumulation is likely only in alkaline soils, and neither molybdenum nor selenium are expected to reach phytotoxic levels in sludge-amended soils (Chang et al. 1986).

Chromium may leach through soils into the underlying ground waters. The U.S. Department of Agriculture has recommended limiting the amount of chromium in sewage sludge that may be added to soils despite chromium's low toxicity to animals (USDA 1978). Municipal sewage sludges seldom exceed these limits except in areas with significant chrome plating or tannery industries (Pennsylvania State University 1985).

Boron toxicity has been found following some sludge applications. Adverse effects on sycamore (Vimmerstedt and Glover 1984) and soybeans (Feuerbacher et al. 1980) have been reported following 
some sludge applications, although these effects may be partially a result of background concentrations of boron in the soil (Barnhisel 1988). Boron leaches readily and so does not accumulate except in arid or semiarid regions (Chang et al. 1986).

Vegetation growing on cadmium-contaminated sludges may accumulate this element (EPA 1983); however, no case of cadmium poisoning has been documented for foods grown on soils amended with municipal sludge (Chang et al. 1986). The EPA regulates the annual and cumulative amounts of cadmium that can be applied to crop lands via the use of sludge (Table 6). Cadmium and polychlorinated biphenyls (PCBs) are the only materials in sludge that are regulated by the EPA when the sludge is applied to land used for the production of animal feed or food-chain crops (40 CFR 257.3-5). Various states and the U.S. Department of Agriculture's regional technical committees recommend controlling sludge application rates on the basis of trace elements other than cadmium. Levels of elements regulated by the State of Washington for agricultural lands are given in Table 7. Acceptable levels for elements in sludge used in the reclamation of disturbed nonagricultural lands have not been set.

TABLE 6. Maximum Annual and Cumulative Cadmium Inputs to Agricultural Crop Land(a)

\begin{tabular}{|c|c|}
\hline$\underline{\text { Soil pH }}$ & Annual Input \\
\hline$<6.5$ & $0.5 \mathrm{~kg} / \mathrm{ha}$ \\
\hline$>6.5$ & $\begin{array}{l}1.25 \mathrm{~kg} / \mathrm{ha} \text { to } \\
0.5 \mathrm{~kg} / \mathrm{ha} \text { in annual } \\
\text { increments }\end{array}$ \\
\hline Soil Cation-Exchange Capacity & Cumulative Input \\
\hline$<5 \mathrm{cmol} / \mathrm{kg}$ & $5 \mathrm{~kg} / \mathrm{ha}$ \\
\hline 5 to $15 \mathrm{cmol} / \mathrm{kg}$ & $10 \mathrm{~kg} / \mathrm{ha}$ \\
\hline$>15 \mathrm{cmol} / \mathrm{kg}$ & $20 \mathrm{~kg} / \mathrm{ha}$ \\
\hline
\end{tabular}

(a) From EPA (1983).

TABLE 7. Total Soil Loading of Sludge Metals Permitted by the State of Washington(a)

\begin{tabular}{lccr} 
& \multicolumn{3}{c}{ Soil Cation-Exchange Capacity, meq $/ 100 \mathrm{~g}$} \\
\hline Metal, kg/ha & $\underline{0 \text { to } 5}$ & $\underline{5 \text { to } 15}$ & $\frac{15}{250}$ \\
Copper & 125 & 1,000 & 500 \\
Lead & 500 & 102 & 2,000 \\
Nickel & 51 & 500 & 205 \\
Zinc & 250 & & 1,000
\end{tabular}

(a) From Ecology (1982a). 
As noted previously, most trace elements are relatively immobile in soils, being strongly complexed with soil organic matter or adsorbed to soil minerals (Bloomfield et al. 1976). Generally, the water solubility of most heavy metals is increased by acid conditions (e.g., Bradshaw and Chadwick 1980). Extensive field studies indicate that sludge applications shift soil $\mathrm{pH}$ to more neutral levels (Chang et al. 1986). At $\mathrm{pH}$ levels near neutral, most metals are relatively immobile in soils, and consequently are seldom found in ground waters or runoff from sludge-amended regions (Morin 1981; Schneider et al. 1981). Zasoski et al. (1984) found little leaching of metals from sludges applied to soils of northwestern forests, despite pH levels below 5 .

Furthermore, most plants do not concentrate trace elements, except cadmium; consequently, cadmium is the only trace element in sludge regulated by the EPA. The EPA does set guidelines for other trace metals in sludge used on agricultural lands where repeated applications of sludge are the rule (Table 8). Sludge use on disturbed landscapes often is employed as a one-time or a few-times application, seldom as a chronic application such as is involved with agricultural uses. Consequently, single-application treatments of sewage sludge are not likely to exceed standards for any trace element (Chang et al. 1986) or to constitute a hazard to plants or animals (Bradshaw and Chadwick 1980).

Synthetic hydrocarbons are found in a small percentage of sludges. PCBs are among the most prevalent of these hydrocarbons, although seldom found in concentrations greater than $10 \mathrm{ppm}$ (Jones 1981). In general, most of the halogenated hydrocarbons are not taken up by plants. Their main entry into the food chain is via ingestion by animals of contaminated soils or plant material with surficial contamination. An effective method of control is to prevent direct grazing immediately following the application of sludges known to contain halogenated hydrocarbons. Because of adsorption by the soil and various decomposition reactions, little leaching of toxic organic constituents is likely to occur, except in the highest precipitation areas (Overcash 1983).

TABLE 8. EPA Guidelines for Total Trace Metal Loadings for Agricultural Lands ${ }^{(a)}$

Metal
Cadmium
Copper
Lead

Nickel

Zinc

(a) From EPA (1983).

\begin{tabular}{rrr}
\multicolumn{3}{c}{ Soil Cation-Exchange Capacity $(\mathrm{meq} / 100 \mathrm{~g})$} \\
\hline$<5$ & $\underline{5 \text { to } 15}$ & $\geq 15$ \\
6 & 11 & 22 \\
140 & 280 & 560 \\
560 & 1120 & 2240 \\
140 & 280 & 560 \\
280 & 560 & 1120
\end{tabular}


Concentrations of artificial halogenated hydrocarbons are low in most sludges. Most synthetic hydrocarbons in sludges are relatively immobile and decompose in the soil (Overcash 1983). Use of proper analysis of sludges for trace organic constituents and appropriate management of land application rates and methods will lessen environmental consequences caused by synthetic organic constituents.

\section{SALT ACCUMULATION}

Heavy applications of sludge, on the order of $896 \mathrm{Mg} / \mathrm{ha}$, may depress plant growth in some instances, presumably as a result of salt accumulation in the soil (Hinesley et al. 1982). This effect is not likely to be a problem for most land reclamation uses where application rates are generally an order of magnitude less than this amount.

Leaching of nitrates into ground water is considered a potential negative factor in the use of all nitrogenous fertilizers. However, sludges are less prone to leaching than are commercial fertilizers. Although the sludge application rate may affect the rate of mineralization of organic nitrogen, no similar effect has been found regarding nitrate production (Sabey et al. 1986). The naturally low levels of nitrifying bacteria in the soil, especially in disturbed soils low in organic material, presumably limit the rate at which the ammonium ion is converted to nitrate (Mengel and Kirkby 1979). 



\section{REGULATORY REOUIREMENTS AFFECTING LAND APPLICATION OF SLUDGE}

Regulatory requirements applicable to use of municipal sewage sludge as a soil supplement on disturbed lands exist at the federal, state, and local level. The basis for the requirements is Section 405 of the federal Clean Water Act (33 USC 1345). Regulatory requirements are currently in a period of transition as EPA implements the directives in Section 405. Municipal sewage sludges, which are determined to be hazardous substances under the EPA regulations at 40 CFR 261 are managed and disposed of under the Resource Conservation and Recovery Act (42 USC 6921-6939b) rather than under Section 405. In addition, the use and disposal of sludge with a PCB concentration greater than $50 \mathrm{ppm}$ are regulated under special regulations at 40 CFR 761 .

Section 405 of the Clean Water Act directs EPA to take a number of steps including

- publishing guidelines for the disposal and utilization of sewage sludge

- promulgating regulations for acceptable management practices for sludge containing toxic pollutants

- providing that permits issued to operators of sewage treatment facilities implement the preceding guidelines and regulations.

EPA promulgated state sludge management program regulations in May 1989 (54 FR 18716); the regulations appear at 40 CFR 501. The regulations cover the procedures that EPA will follow in approving, revising, and withdrawing state sludge management programs operating under Section 405. Under the regulations, all sewage treatment works (including those owned by the federal government) are required to have a permit from EPA or from a state with an EPA-approved program (40 CFR 501.15). The definition of treatment works includes sludge monofills (sludge-only landfills), sludge incinerators, and dedicated land disposal sites (54 FR 18730). Recipients of sewage sludge who apply the sludge to land for beneficial purposes are not required to have a permit (54 FR 18731). States are allowed sludge management programs that are more stringent or extensive than the federal requirements [ $40 \mathrm{CFR}$ 501.1(i)].

EPA has also published proposed technical standards for the use and disposal of sewage sludge (54 FR 5746). The proposed regulations establish requirements for the final use and disposal of sewage sludge when the sludge is applied to land, distributed and marketed, placed in monofills or on surface disposal sites, or incinerated. The regulations are to be codified at 40 CFR 503. EPA's current schedule calls for issuance of the final regulations in October 1991 (55 FR 16848). Subpart B of the proposed Part 503 regulations covers the land application of sewage sludge. The proposed regulations (40 CFR 503.12) require that operators of treatment works enter into an agreement with the distributor or applier of sewage sludge to comply with Subpart B. Subpart B includes requirements for agricultural and nonagricultural land. The agricultural land requirements include maximum annual and cumulative 
loading rates for various pollutants and four mandatory management practices. The requirements for sludge application to nonagricultural land include maximum concentration levels in the sludge for 22 pollutants and 6 mandatory management practices.

EPA has existing requirements covering land application of sewage sludge at 40 CFR 257. In particular, 40 CFR 257.3-5 places restrictions on the application of sludge containing cadmium and PCBs to land used for the production of food-chain crops, and 40 CFR 257.3-6 requires treatment to significantly reduce pathogens before land application. EPA plans to have the Part 503 regulations supersede the provisions in Part 257 applicable to land disposal of sludge (54 FR 5876).

EPA reported in 1989 that 42 states had regulations or guidelines covering the land application of sewage sludge that set either a maximum allowable pollutant concentration or maximum pollutant loading rate (54 FR 5758). Most of these regulations and guidelines will need to be amended to adopt the requirements in the Part 501 regulations and the Part 503 technical standards, when they become final. The State of Washington, for example, currently requires [WAC 173-304-300(4) and WAC 173304-450] that facilities utilizing sewage sludge comply with the Washington Department of Ecology's sludge utilization guidelines (Ecology 1982a) and meet a number of additional requirements. 


\section{MEASURES TO MINIMIZE ADVERSE IMPACTS}

A number of mandatory and voluntary measures to limit the potential adverse effects of land application of sewage sludge have been implemented as a result of various statutes, regulations, and guidelines. Measures include defining design criteria for land application programs (e.g., EPA 1983); assessing risks to wildlife and human health associated with pathogens, halogenated hydrocarbons, and heavy metals (Munger 1986); permitting for sludge use by state and/or local health departments; land-use restrictions; application rate restrictions; monitoring requirements; sludge analysis requirements regarding metals, nitrogen, and halogenated hydrocarbons; and refinement and codification of operational procedures covering production, transport, application systems, year-round operation, storage, and other aspects of sludge management (e.g., Ecology 1982a, 1982b; Rogers 1986).

Most of the guidelines regarding sludge application suggest that application rates be calculated on the basis of nitrogen and other plant nutrient requirements, as well as the potential for concentrating heavy metals in the soil. Guidelines for onsite storage depend on whether liquid or dewatered sludges are used. Below 15\% solids, most sludges act as semisolids (Henry et al. 1986) and require an earthen basin (lagoon), usually with a water-impermeable liner, or above- or below-ground tanks for onsite storage (Ecology 1982b). Dewatered sludges are more economical for transport over distances greater than $15 \mathrm{~km}$ (Henry et al. 1986). All proposed storage facilities in the State of Washington require approval by the Washington Department of Ecology before use (Ecology 1982b). Reclamation plans for the storage facility may also be required.

To avoid potential runoff, sludge applications should be timed such that sludge is thoroughly incorporated with the soil before maximum periods of rainfall. Suggested application methods may be found in the appropriate guidelines (e.g., Ecology 1982b). Alternative application systems are identified in Table 9.

Controls may be placed on the generation and treatment of sludges to limit the influx of toxic substances and the content of pathogens. For example, industry constitutes the largest source of metals in most sewage treatment facilities. The use of pretreatment methods at these sources can significantly decrease the levels of toxic substances in the facility's sludge. Anaerobic digestion of waste streams reduces the number of bacteria and viruses in the waste stream by about $90 \%$ in comparison to aerobic digestion (Munger 1983).

Control of pathogens in land application of sludges can be achieved through a number of methods. Wastewater treatment processes provide the first line of control. Bacteria and viruses become associated with the sediment, whereas most parasitic cysts and eggs exit the system in the liquid component (Sorber and Moore 1986). Disinfection can reduce the concentration of bacteria and viruses to 
TABLE 9. Sludge Application Systems ${ }^{(a)}$

\begin{tabular}{lc}
\multicolumn{1}{c}{ System } & $\begin{array}{c}\text { Application } \\
\text { Range (m) }\end{array}$ \\
\cline { 1 - 2 } Liquid Sludge & 60 \\
$\quad$ Spray irrigation & 60 \\
$\quad$ Application vehicle with spray cannon & 3 \\
$\quad$ Direct spreading & \\
Semisolid Sludge & 45 \\
$\quad$ Application vehicle with spray cannon & 3 \\
$\quad$ Direct spreading & \\
Solid Sludge & 15 \\
$\quad$ Manure-type spreader &
\end{tabular}

(a) From Henry et al. (1986).

below the 50\% infectious dose levels (Sorber and Moore 1986); however, such treatments eliminate one benefit of sludge as a soil amendment for drastically disturbed lands (i.e., the microbial populations in the sludge that assist in the formation of a living, functional topsoil). Other treatment options for controlling pathogen levels in sludge are listed in Table 10.

Monitoring programs are generally required where high concentrations of toxic elements and/or organic compounds are present in sludge-amended soils (e.g., Ecology 1982b). The potential for nitrate leaching can be minimized by matching sludge application rates to nitrogen conversion rates and plant uptake rates (e.g., Ecology 1982b). In arid and semiarid regions where soil profiles have been significantly disturbed, nitrate leaching is unlikely because of the very slow conversion of ammonium to nitrate under those conditions (Sabey et al. 1986). The State of Washington Department of Ecology requires monitoring surface water flows from sludge-treated areas and monitoring of ground waters from wells upgradient and downgradient from the treated areas. Soil sampling before and after the application of sludges is also suggested (Ecology 1982b).

Information about sludge characteristics, application site characteristics, storage methods, application rates and times, and expected land use are required as part of the permitting process in the State of Washington (Ecology 1982b). 
TABLE 10. Effectiveness of Various Sludge Treatment Processes in the Reduction of Pathogens (a)

\begin{tabular}{l}
\multicolumn{1}{c}{ Treatment Process } \\
Mesophilic anaerobic digestion \\
Aerobic digestion \\
Composting \\
Air drying \\
Lime stabilization \\
\hline
\end{tabular}

\begin{tabular}{ccc}
\multicolumn{3}{c}{$\log 10$ Reductions } \\
\hline Bacteria & $\frac{\text { Parasites }}{2}$ & $\frac{\text { Viruses }}{0.5 \text { to } 4}$ \\
0.5 to 4 & $<0.5$ & 0.5 to 2 \\
2 to $>4$ & 20.5 & 0.5 to 2 \\
0.5 to $>4$ & 0.5 to $>4$ & 2 to $>4$ \\
2 to $>4$ & $<0.5$ & 0.5 to $>4$ \\
& & $>4$
\end{tabular}

(a) From Sorber and Moore (1986).

Public concerns about land application of sewage sludge tend to center primarily around health risk issues, environmental protection, and nuisances such as odor. Additional concerns include cultural and historical precedents and attitudes and perceptions of land owners or managers. Through implementation of a regulated, permitted, and well-managed program of sludge application, concerns over health, environment, and nuisances can be minimized. Public education regarding the benefits and risks associated with all forms of soil amendments, including commercial fertilizers, herbicides and pesticides, and animal by-products (including treated human sewage), may be the only effective counter to adverse attitudes based on bad precedent and lack of information (Forster and Southgate 1983). 



\section{REFERENCES}

Aldon, E. F. 1982. "Use of Organic Amendments for Biomass Production on Reclaimed Strip Mines in the Southwest." In Land Reclamation and Biomass Production with Municipal Wastewater and Sludge, eds. W. E. Sopper, E. M. Seaker, and R. K. Bastain, pp. 317-320. The Pennsylvania State University Press, University Park, Pennsylvania.

Allaway, W. H. 1968. "Agronomic Controls Over the Environmental Cycling of Trace Elements." Adv. Agron. 20:235-274.

Barnhisel, R. I. 1988. "Fertilization and Management of Reclaimed Lands." In Reclamation of SurfaceMined Lands, Volume II, ed. L. R. Hossner, pp. 1-15. CRC Press, Inc., Boca Raton, Florida.

Bastian, R. K. 1986. "Overview on Sludge Utilization." In The Forest Alternative for Treatment and Utilization of Municipal and Industrial Wastes, eds. D. W. Cole, C. L. Henry, and W. L. Nutter, Pp. 725. University of Washington Press, Seattle, Washington.

Biondini, M. E., C. D. Bonham, and E. F. Redente. 1985. "Relationships Between Induced Successional Patterns and Soil Biological Activity of Reclamation Areas." Reclam. Reveg. Res. 3:323-342.

Bloomfield, C., W. I. Kelso, and G. Pruden. 1976. "Reactions Between Metals and Humidified Organic Matter." Soil Science 27:16-31.

Bowen, H. J. M. 1979. Environmental Chemistry of the Elements. Academic Press, London.

Box, T. W. 1978. "The Significance and Responsibility of Rehabilitating Drastically Disturbed Land." In Reclamation of Drastically Disturbed Lands, eds. F. W. Shaller and P. Sutton, pp. 1-10. American Society of Agronomists, Madison, Wisconsin.

Bradshaw, A. D., and M. J. Chadwick. 1980. The Restoration of Land. University of California Press, Berkeley, California.

Brown, L. T., and C. L. Jackson. 1984. "Reclamation of the URAD Molybdenum Mine." Minerals and the Environment 2:77-82.

Chaney, R. L. 1980. "Health Risks Associated with Toxic Metals in Municipal Sludges." In Sludge: Health Risks of Land Application, eds. G. Bitton, B. L. Damron, G. T. Edds, and J. M. Davidson, pp. 5983. Ann Arbor Science Publishers, Ann Arbor, Michigan.

Chang, A. C., T. J. Logan, and A. L. Page. 1986. "Trace Element Considerations of Forest Land Applications of Municipal Sludges." In The Forest Alternative for Treatment and Utilization of Municipal and Ind ustrial Wastes, eds. D. W. Cole, C. L. Henry, and W. L. Nutter, Pp. 85-99. University of Washington Press, Seattle, Washington.

Damgaard-Larsen, S., K. O. Jensen, E. Lund, and B. Nissen. 1977. "Survival and Movement of Enterovirus in Connection with Land Disposal of Sludges." Water Res. 11:503-508.

Doerr, T. B., and E. F. Redente. 1983. "Seeded Plant Community Changes on Intensively Disturbed Soils Affected By Cultural Practices." Reclam. Reveg. Res. 2:13-24.

Ecology. 1982a. Municipal and Domestic Sludge Utilization Guidelines. WDOE 82-11, State of Washington Department of Ecology, Tacoma, Washington. 
Ecology. 1982b. Best Management Practices for Use of Municipal Sewage Sludge. WDOE 82-12, State of Washington Department of Ecology, Tacoma, Washington.

EPA. 1979. A History of Land Application as a Treatment Alternative. MCD-40, Office of Water Program Operations, U.S. Environmental Protection Agency, Washington, D.C.

EPA. 1983. Process Design Manual: Land Application of Municipal Sewage Sludge. EPA 625/1-83-016, U.S. Environmental Protection Agency, Cincinnati, Ohio.

EPA. 1984. Environmental Regulations and Technology: Use and Disposal of Municipal Wastewater Sludge. EPA 625/10-84-003, U.S. Environmental Protection Agency, Washington, D.C.

Epstein, E., D. B. Keane, J. J. Meisinger, and J. O. Legg. 1978. "Mineralization of Nitrogen from Sewage Sludge and Sludge Components." J. Environ. Qual. 7:217-221.

Feuerbacher, T. A., R. I. Barnhisel, and M. D. Ellis. 1980. "Utilization of Municipal Sewage Sludge as a Spoil Amendment in the Reclamation of Lands Surface Mined for Coal." In Symposium on Surface Mining Hydrology, Sedimentology, and Reclamation, ed. D. Graves, pp. 187-195. OES Publication UKY BU126, University of Kentucky, Lexington, Kentucky.

Forster, D. L., and D. D. Southgate. 1983. "Institutions Constraining the Utilization of Municipal Wastewater and Sludge on Land." In Proceedings of the 1983 Workshop on Utilization of Municipal Wastewater and Sludge on Land, eds. A. L. Page, T. L. Gleason III, J. E. Smith, Jr., I. K. Iskandar, and L. E. Sommers, pp. 29-43. University of California, Riverside, California.

Fresquez, P. R., and W. C. Lindemann. 1982. "Soil and Rhizosphere Microorganisms in Amended Coal Mine Spoils." Soil Sci. Soc. Am. J. 46:751-755.

Gerba, C. P. 1983. "Pathogens." In Proceedings of the 1983 Workshop on Utilization of Municipal Wastewater and Sludge on Land, eds. A. L. Page, T. L. Gleason III, J. E. Smith, Jr., I. K. Iskandar, and L. E. Sommers, pp. 147-187. University of California, Riverside, California.

Henry, C. L., C. G. Nichols, and T. J. Chang. 1986. "Technology and Costs of Forest Sludge Applications." In The Forest Alternative for Treatment and Utilization of Municipal and Industrial Wastes, eds. D. W. Cole, C. L. Henry, and W. L. Nutter, pp. 356-366. University of Washington Press, Seattle, Washington.

Hinesley, T. D., K. E. Tedbord, E. L. Ziegler, and I. H. Rose-Innes. 1982. "Effects of Chemical and Physical Changes in Strip-Mined Spoil Amended with Sewage Sludge on the Uptake of Metals by Plants." In Land Reclamation and Biomass Production with Municipal Wastewater and Sludge, eds. W. E. Sopper, E. M. Seaker, and R. K. Bastain, pp. 339-352. The Pennsylvania State University Press, University Park, Pennsylvania.

Howard, G. S., G. E. Schuman, and F. Rauzi. 1977. "Growth of Selected Plants on Wyoming SurfaceMined Soils and Flyash." J. Range Mgmt. 30:306-310.

Jones, U. S. 1981. Fertilizers and Soil Fertility. 2nd Ed, Reston Publishing Co., Inc., Reston, Virginia.

Logan, T. J., and R. L. Chaney. 1983. "Utilization of Municipal Wastewater and Sludge on Land Metals." In Proceedings of the 1983 Workshop on Utilization of Municipal Wastewater and Sludge on Land, eds. A. L. Page, T. L. Gleason III, J. E. Smith, Jr., I. K. Iskandar, and L. E. Sommers, pp. 235-323. University of California, Riverside, California. 
Mengel, K., and E. A. Kirkby. 1979. Principles of Plant Nutrition. International Potash Institute, Bern, Switzerland.

Morin, M. D. 1981. "Heavy Metal Concentrations in Three-Year Old Trees Grown on Sludge-Amended Surface Mine Spoil." In Proceedings: 1981 Symposium on Surface Mining Hydrology, Sedimentology, and Reclamation, ed. D. H. Graves, pp. 297-306. OES Publication UKY BU126, University of Kentucky, Lexington, Kentucky.

Munger, S. 1983. Health Effects of Municipal Wastewater Sludge - A Risk Assessment. Municipality of Metropolitan Seattle, Seattle, Washington.

Munger, S. 1986. "Forest Land Application of Municipal Sludge: The Risk Assessment Process." In The Forest Alternatioe for Treatment and Utilization of Municipal and Industrial Wastes, eds. D. W. Cole, C. L. Henry, and W. L. Nutter, pp. 117-124. University of Washington Press, Seattle, Washington.

NAS. 1977. Multimedia Management of Municipal Sludge. Analytical Studies for the U.S. Environmental Protection Agency, Vol. 9. National Academy of Science, Washington, D.C.

Odum, E. P. 1969. "The Strategy of Ecosystem Development." Science 164:262-270.

Overcash, M. R. 1983. "Land Treatment of Municipal Effluent and Sludge: Specific Organic Compounds." In Proceedings of the 1983 Workshop on Utilization of Municipal Wastewater and Sludge on Land, eds. A. L. Page, T. L. Gleason III, J. E. Smith, Jr., I. K. Iskandar, and L. E. Sommers, pp. 199-277. University of California, Riverside, California.

Overcash, M. R., and J. B. Weber. 1986. "Behavior of Organic Compounds in Land Treatment Systems with the Presence of Municipal Sludge." In The Forest Alternative for Treatment and Utilization of Municipal and Industrial Wastes, eds. D. W. Cole, C. L. Henry, and W. L. Nutter, pp. 125-131. University of Washington Press, Seattle, Washington.

Page, A. L., A. C. Chang, G. Sposito, and S. Mattigod. 1981. "Trace Elements in Wastewater: Their Effects on Plant Growth and Composition and Their Behavior in Soils." In Modeling Wastewater Renovation Land Treatment, ed. I. K. Iskandar, pp. 182-222. John Wiley and Sons, New York.

Parker, C. F., and L. E. Sommers. 1983. "Mineralization of Nitrogen in Sewage Sludges." L. Environ. Qual. 12:150-156.

Pennsylvania State University. 1985. Criteria and Recommendations for Land Application of Sludges in the Northeast. Bulletin 851, The Pennsylvania State University, Agricultural Experiment Station, Philadelphia, Pennsylvania.

Reeder, J. D., and W. A. Berg. 1977. "Nitrogen Mineralization and Nitrification in a Cretaceous Shale and Coal Mine Spoil." Soil Sci. Soc. Am. J. 41:922-930.

Rodgers, W. H., Jr. 1986. Environmental Law, Air and Water. Vol. 2. West Publishing Co., St. Paul, Minnesota.

Sabey, B. R., N. N. Agbim, and D. C. Markstrom. 1977. "Land Application of Sewage Sludge: IV. Wheat Growth, $N$ Content, $N$ Fertilizer Value, and N Use Efficiency as Influenced by Sewage Sludge and Wood Waste Mixtures." I. Environ. Qual. 6:52-58. 
Sabey, B. R., K. Topper, and G. Voos. 1986. "Use of Sewage Sludge for Reclamation of Coal Mine Spoils." In Proceedings: High Altitude Revegetation Workshop No. 7, eds. M. A. Schuster and R. H. Zuck, pp. 158-186. Colorado State University, Fort Collins, Colorado.

Schneider, K. R., R. F. Wittwer, and S. B. Carpenter. 1981. "Trees Respond to Sewage Sludges in Reforestation of Acid Spoil." In Proceedings: 1981 Symposium on Surface Mining Hydrology, Sedimentology, and Reclamation, ed. D. H. Graves, pp. 291-296. OES Publication UKY BU126, University of Kentucky, Lexington, Kentucky.

Sobsey, M., and B. Olson. 1983. "Microbial Agents of Waterborne Disease." In Assessment of Microbiology and Turbidity Standards for Drinking Water. EPA-570/9-83-001, U.S. Environmental Protection Agency, Washington, D.C.

Sopper, W. E., and S. N. Kerr. 1981. Revegetating Strip-Mined Land with Municipal Sewage Sludge. EPA-600/2-81-182, U.S. Environmental Protection Agency, Cincinnati, Ohio.

Sopper, W. E., and E. M. Seaker. 1983. A Guide for Revegetation of Mined Land in Eastern United States Using Municipal Sludge. The Pennsylvania State University Press, University Park, Pennsylvania.

Sopper, W. E., S. N. Kerr, and E. M. Seaker. 1981. "The Pennsylvania Program for Using Municipal Sludge for Mine Land Reclamation." In Proceedings: 1981 Symposium on Surface Mining Hydrology, Sedimentology, and Reclamation, ed. D. H. Graves, pp. 283-290. OES Publication UKY BU126, University of Kentucky, Lexington, Kentucky.

Sorber, C. A., and B. E. Moore. 1986. "Microbiological Aspects of Forest Application of Wastewater and Sludge." In The Forest Alternative for Treatment and Utilization of Municipal and Industrial Wastes, eds. D. W. Cole, C. L. Henry, and W. L. Nutter, pp. 73-84. University of Washington Press, Seattle, Washington.

Terry, R. E., D. W. Nelson, and L. E. Sommers. 1981. "Nitrogen Transformation in Sewage Sludge Amended Soils as Affected by Soil Environmental Factors." Soil Sci. Soc. Am. J. 45:506-513.

Urie, D. H. 1986. "The Status of Wastewater Irrigation of Forests, 1985." In The Forest Alternative for Treatment and Utilization of Municipal and Industrial Wastes, eds. D. W. Cole, C. L. Henry, and W. L. Nutter, pp. 26-40. University of Washington Press, Seattle, Washington.

USDA. 1978. Improving Soils With Organic Wastes. Report to Congress. U.S. Department of Agriculture, U.S. Government Printing Office, Washington, D.C.

Vimmerstedt, J. P., and T. N. Glover. 1984. "Boron Toxicity to Sycamore of Minesoil Mixed with Sewage Sludge Containing Glass Fibers." Soil Sci. Soc. Am. J. 48:389-394.

Woodward, D. K., H. Campa III, and J. B. Haufler. 1986. "The Influence of Forest Application of Sewage Sludge on the Concentration of Metals in Vegetation and Small Mammals." In The Forest Alternative for Treatment and Utilization of Municipal and Industrial Wastes, eds. D. W. Cole, C. L. Henry, and W. L. Nutter, pp. 199-205. University of Washington Press, Seattle, Washington.

Zasoski, R. J., R. L. Edmonds, C. S. Bledsoe, C. L. Henry, D. J. Vogt, K. A. Vogt, and D. W. Cole. 1984. "Municipal Sewage Sludge Use in Forests of the Pacific Northwest, U.S.A.: Environmental Concerns." Waste Management and Research. 2:227-246. 


\section{DISTRIBUTION}

No. of

Copies

\section{$\underline{\text { OFFSITE }}$}

2 DOE/Office of Scientific and Technical Information

ONSITE

3 DOE Richland Operations Office

J. H. Anttonen

J. D. Furubotten

A. G. Lassila

5 Westinghouse Hanford Company

C. R. Haggerty

D. E. Mahagin

J. E. Thrasher

P. H. Turner

BWIP Records Center

$4 \quad$ Kaiser Engineers Hanford

K. C. Burgard

R. E. Grant

N. M. Hutchins

R. L. Newell
No. of

Copies

45 Pacific Northwest Laboratory

C. A. Brandt (10)

N. A. Cadoret

D. D. Dauble

J. W. Falco

R. H. Gray (5)

J. M. Hales

P. C. Hays

P. L. Hendrickson

R. E. Lundgren

T. L. Page

W. T. Pennell

W. H. Rickard, Jr. (10)

L. E. Rogers

R. L. Skaggs

J. B. States

H. E. Westerdahl

R. K. Woodruff

Publishing Coordination

Technical Report Files (5) 